\title{
LEGAL PROTECTION OF LABOR RIGHTS DURING THE CORONAVIRUS DISEASE 2019 (COVID-19) PANDEMIC
}

\author{
Fachry Ahsany \\ Faculty of Law, University of Muhammadiyah Malang, East Java, Indonesia \\ fachry.ahsany99@gmail.com \\ Ahmad Faiz Alamsyah \\ Faculty of Law, University of Muhammadiyah Malang, East Java, Indonesia \\ ahmadfaizalamsyah123@gmail.com \\ Sholahuddin Al-Fatih \\ Faculty of Law, University of Muhammadiyah Malang, East Java, Indonesia \\ sholahuddin.alfath@gmail.com
}

\begin{abstract}
Since the Coronavirus Disease 2019 (Covid-19) pandemic in Indonesia, which continues to grow and has an impact, not a few companies have gone bankrupt. Whether it's a small company, a medium sized company or even a large corporation are affected by the Coronavirus Disease 2019 (Covid-19). This paper aim to find legal issues on labor right during Covid-19 pandemic in Indonesia. Using the normative legal research, this paper analyze some of regulation and legal government act to protect labor right who terminated (Pemutusan Hubungan Kerja/PHK) during Covid-19 pandemic. In the end, this paper find that the government issued two program to solve PHK and protect labor rights, namely Pre-Works Card and Cash Incentive Program (Bantuan Langsung Tunai/BLT). It's actively help employee to create a new job and continue their daily life.
\end{abstract}

Keyword: Covid-19, Labor Rights, Legal Protection, Pandemic.

\section{A. INTRODUCTION}

The Coronavirus Disease 2019 (Covid-19) outbreak initially occurred in December 2019 in Wuhan City, Hubei Province, China. Wuhan is the most populous city in central China with a population of approximately 11 million. Some of the patients indicated to have this virus have symptoms such as fever, fatigue, dry cough, shortness of breath, joint problems, excessive phlegm, sore throat, cold, headache, vomiting, diarrhea, hemoptysis, and nasal congestion. All events in these patients were indicated to be infected at the market in Wuhan, famous for trading various kinds of fish, live animals and animals even animals that are not traded in other markets such as bats and snakes. This is known because research has been carried out by the Chinese Center for Disease Control and Prevention (CCDC) on January 7, 2020, and was later named Acute Aconavirus 2 (SARS-CoV-2). The disease was named Coronavirus Disease 2019 (Covid-19) by the World 
Health Organization (WHO). ${ }^{1}$

In China, this outbreak was declared by the World Health Organization / Barometer (WHO). On January 30, 2020, it became a public health emergency with international concern creating a high risk for countries with vulnerable health systems. The emergency committee has stated that the spread of Coronavirus Disease 2019 (Covid-19) may be disrupted by early detection, isolation, prompt maintenance, and the implementation of a strong system for tracking other key contacts because the goal to be achieved is the establishment of a certainty regarding clinical severity and the extent of transmission. The main objective is to minimize the economic impact of viruses and to overcome misinformation on a global scale. $^{2}$

Until May 2020, this virus has been infected by more than 200 countries around the world. Not only the impact of death is very high generated by this virus, but also various sectors of the joints of life are also affected by the presence of a virus that can be labeled this pandemic because it has spread throughout the world. Of the various joints of life, one of them is affected, namely Economy. One of the countries affected in its economic sector is our country, Indonesia. The economic sector which was affected both in terms of tourism, investment and trade was astonished if the Indonesian economy lately was seen declining or sluggish than usual. The Indonesian government is handling fast handling of the 2019 Corona Virus Disease (Covid-19) outbreak. Steps taken are enacting social distancing and issuing legislation products in the form of Government Regulation Number 21 of 2020 concerning Large-Scale Social Restrictions (PSBB), and the existence of Minister of Health Regulation (PMK) Number 9 of 2020 concerning Large-Scale Social Limitation Guidelines (PSBB) with the aim of fast handling of this plague. In these regulations, it also regulates what work can or can work outside or can only do Work from Home or known as Work from Home (WFH). and the existence of Minister of Health Regulation (PMK) No. 9 of 2020 concerning the Guidelines for Large-Scale Social Restrictions (PSBB) with the aim of creating a fast response to this outbreak. In these regulations, it also regulates what work can or can work outside or can only do Work from Home or known as Work from Home (WFH). and the existence of Minister of Health Regulation (PMK) No. 9 of 2020 concerning the Guidelines for Large-Scale Social Restrictions (PSBB) with the aim of creating a fast response to this outbreak. In these regulations, it also regulates what work can or can work outside or can only do Work from Home or known as Work from Home (WFH).

Employment has also been affected by this epidemic, whether formal or informal. As we have seen in the field, many companies have gone bankrupt. Whether it is small, medium, or large companies even affected by the existence of this virus that is by terminating the Employment Relations

1 Catrin Sohrabi et al., World Health Organization Declares Global Emergency: A Review of the 2019 Novel Coronavirus (Covid-19), International Journal of Surgery, 76 (April 1, 2020), Page. 71-76

2 Ibid. 
(PHK) on its workers or labors. It was forced to be the last resort undertaken by the company because it was to reduce the amount of expenditure that was not in accordance with the amount of revenue. Actions taken by employers or job owners in the form of Termination of Employment (PHK) result in a decrease in labor welfare or even misery due to loss of work.

As we know, one thing that is also important for the wider community is the existence of work in order to be able to continue their lives because under the pretext of work as a source of life. Work can be interpreted as an effort to maintain life for a person and his family. Work is one of the human rights possessed by someone, therefore one's work must be respected. The significance of the existence of work for the community or for a person is stated in the 1945 Constitution of the Republic of Indonesia, namely that contained in Article 27 paragraph (2) which states that "Every citizen of the Republic of Indonesia has the right to work and a decent living for humanity."

The Corona Virus Disease 2019 (Covid-19) outbreak also affected the trade sector's tax revenue which in this case experienced a decrease which before Indonesia pandemic struck Indonesia Indonesia's trade had the second largest contribution in terms of tax revenue. From several countries affected by the epidemic implementing several restrictions in their countries, Indonesia has also imposed or imposed restrictions and stops on overseas travel to expedite the termination of transmission of Corona Virus Disease 2019 (Covid-19). With the ban, some airlines canceled flights and refunded several flights. However, there are some airlines that are forced to make flights even though the most of the seats are empty to meet the rights of passengers and airline obligations. ${ }^{3}$

According to the Statistics Agency, the number of workers or labors in the State of Indonesia in February 2019 consisted of approximately 136.18 million workers. That number is almost half of the total population of all of Indonesia, therefore workers are an important meaning for the Indonesian government, not only the government, the company also feels that the presence of workers is a major factor for the existence of the company. Therefore, this worker or laborer needs to be given legal protection. Material and prevention of accidents are included in the Protection. Because for them, both are basic things for workers in carrying out their work.

Then the estuary of the protection of these workers is expected to be able to exercise their rights, especially in terms of safety and health. Fundamental benchmarks of the fulfillment of a right and protection in carrying out their work for workers / laborers is the existence of rules regarding employment development to create a conducive work environment.

One proof the government is concerned with the existence of workers or laborers, the government created several laws that regulate the

3 Silpa Hanoatubun, Dampak Covid - 19 Terhadap Perekonomian Indonesia, EduPsyCouns: Journal of Education, Psychology and Counseling, 2, no. 1 (April 14, 2020), Page. 146-53 
world of workers or labors. One of them is ratifying international labor organization (ILO) conventions. Legal protection obtained by workers includes protection for job opportunities, safety at work and health.

Here are some of the results of laws made by the Government relating to workers or labors. UU no. 21 of 2000 concerning Trade Unions, Law No. 13 of 2003 concerning Manpower, Law No. 3 of 1992 concerning Workers' Social Security (JAMSOSTEK), Law no. 1 of 1970 concerning Work Safety, and Law No. 2 of 2004 concerning Settlement of Industrial Relations Disputes. And other regulations governing this labor problem.

The above legal regulations are regulations made by the government because of their obligations, but besides that these regulations also have goals that have a positive impact because they are regulations that govern the relations of government, employers and workers. In addition, these regulations also serve as a foundation for the protection of labor rights which are often positioned as objects under employers.

Detailed legal protection obtained by workers is freedom for workers to improve their standard of living, prevent the reduction or loss of income and purchasing power of workers, as well as protection for job loss due to illness or death. ${ }^{4}$ For workers it becomes the legal basis for their legal protection. Employers are required to carry out forms of protection for workers, namely in the form of maintenance and to provide more welfare good for laborers. This was carried out with a joint guarantee based on kinship and togetherness in accordance with Pancasila and the 1945 Constitution.

Based on Law Number 21 Year 2000 Trade Unions / labor unions are formed with freedom, openness, independence, democracy and a sense of responsibility to fight for the interests of workers and their families. In accordance with Article 102 paragraph (2), in carrying out their work, workers must also comply with their obligations, such as maintaining order, that is done to maintain sustainability or the course of production, be democratic in carrying out or expressing their aspirations, and develop their skills and expertise in participating in advancing and fighting for the company is also fighting for the welfare of members and families. ${ }^{5}$

Because with a situation like this (the existence of the Covid pandemic - 19) it affects the workers in getting their rights. Therefore, the title of this research is Legal Protection of Workers' Rights Amid the Coronavirus Disease 2019 Pandemic (Covid-19). This paper aim to find legal issues on labor right during Covid-19 pandemic in Indonesia.

\section{B. RESEARCH METHODS}

The research method used in this paper is the Normative legal

4 Ashabul Kahfi, Perlindungan hukum terhadap tenaga kerja, Jurnal Jurisprudentie, 3, no. 2 (December 1, 2016), Page. 59

5 Jauhari Ginting and Indah Kurnia Ningsih, Perlindungan hukum terhadap pekerja pt. mara jaya dalam hal kebebasan berserikat menurut Undang-undang RI nomor 21 tahun 2000 tentang serikat pekerja, Jurnal Hukum Kaidah: Media Komunikasi Dan Informasi Hukum Dan Masyarakat 19, no. 1 (2019), Page. 69 
research. Normative legal research methods are legal research within the realm of law in its broadest sense. It is said in its broadest meaning, because jurisprudence is indeed the way it is, entering all aspects of science with the aim of functioning of the law in achieving its objectives. According to Soerjono Soekanto said that legal research carried out by examining mere library materials or secondary data, can be called normative legal research or library legal study. Normative legal research does not only study law in the sense of laws and regulations, but also covers a broader aspect, everything that can be traced through library materials. ${ }^{6}$

This research method is based on primary law and secondary law, which primary law refers to Law No. 21 of 2000 concerning Trade Unions, Law No. 13 of 2003 concerning Manpower, Law No. 3 of 1992 concerning Labor Social Security (JAMSOSTEK), Law No. 1 of 1970 concerning Work Safety, Law No. 2 of 2004 concerning Settlement of Industrial Relations Disputes and for secondary legal sources which includes explanatory data regarding the law those primers, results research in the form of journals, articles or law books related to with the topics discussed.

\section{DISCUSSION}

\section{State Obligations in Work Welfare}

Indonesia is a state of law, and it is known to the public because it can be seen from the current state of Indonesia. This is in accordance with the 1945 Constitution article 1 paragraph 3 which reads "(3) The State of Indonesia is a state of law." Therefore Indonesia guarantees the fulfillment and protection of human rights. The state has an obligation on the survival of its citizens. This guarantee can be seen in the implementation of legal protection of labor rights. The guarantee includes matters that support work and livelihoods which aim to be suitable for the life of the workers themselves.

Limitation on the wife of a worker or worker is regulated in Article 1 number 2 of Law Number 13 Year 2003 Regarding Manpower which reads:

"Work or labor is every person who works by receiving wages or other forms of compensation". The limitation of the term Trade Unions or Workers regulated in Article 1 number 1 of Law Number 21 Year 2001 Concerning Trade Unions or Labor, in essence, the Union of Workers or laborers is organization intended for workers in terms of or within the scope of the company or outside it. That is useful to fight for and defend rights and obligations and protect themselves in improving the welfare of workers or laborers and their families. Where it is free, open, independent, and democratic. ${ }^{7}$

Explanation of this definition explains Freedom is that as an

6 N Qamar et al., Metode Penelitian Hukum (Legal Research Methods), CV. Social Politic Genius (SIGn), Makassar, 2017

7 Yosephine Marcella and Komang Pradnyana Sudibya, Peran Organisasi Serikat Pekerja/Buruh Dalam Pembangunan Perekonomian Indonesia, Kertha Semaya: Journal Ilmu Hukum, 4, no. 3 (2018), Page. $1-15$ 
organization in carrying out its rights and obligations, trade unions or trade unions, federations and confederations of trade unions or labor unions are not under the influence or pressure of other parties. Openness such as trade unions or trade unions, federations and confederations of trade unions or trade unions in accepting members and or fighting for the interests of labor workers does not distinguish between political, religious, ethnic and gender groups or in short there is no discrimination. Independent means that in establishing, implementing and building an organization determined by its own strength is not controlled by other parties from outside the organization. Democratic is that in the founding of an organization, the election of administrators, fighting for and exercising organizational rights and obligations is carried out in accordance with democratic principles. Responsibility is very important because in achieving its objectives and carrying out the rights and obligations of trade unions or labor unions, federations and confederations of trade unions or trade unions are accountable to members, the community and the state. ${ }^{8}$

Workers 'or workers' welfare is important because it is a form of their way of meeting family needs both physically and mentally. Which is done by workers or laborers outside the employment relationship which is directly or even indirectly in order to prioritize their performance. With the comfort and convenience provided by various facilities provided by the company is a form of providing welfare received by workers. ${ }^{9}$

To express the participation or aspirations of workers or laborers in the business world and the industrial world, a kind of union of workers or laborers can be formed to realize industrial participation through organizations or companies. A trade union or trade union can be formed in one or more companies and can be merged into a federation, and its formation can be planned with a sufficiently long time period and takes place continuously and is carried out consistently with the aim to improve or develop cooperative relations and joint responsibility, both between workers and between workers and employers. The right to associate or organize is seen as an absolute necessity and must be fulfilled as a means of fighting for the creation of workers or labor rights such as the right to wages; the right of workers or women workers to reproductive functions and the right to health; and work safety. ${ }^{10}$

In addition to organizing government, Indonesia is also obliged to conduct public welfare, including ensuring that the state is involved in the field of labor activities. Indonesia's identity as a welfare state has been stated in the preamble of the 1945 Law, alenia 4 (four). Consequences Indonesia as a welfare state, the state must get involved in people's

8 SW Handayani, Jaminan Pemerintah Negara Republik Indonesia Terhadap Penyelenggaraan Serikat Pekerja Sebagai Hak Azasi Manusia, Kosmik Hukum, 16, no. 1 (2016), Page. 7

9 G Hendrastomo, Menakar Kesejahteraan Buruh: Memperjuangkan Kesejahteraan Buruh Diantara Kepentingan Negara Dan Korporasi, Jurnal Informasi, 16, no. 2 (2010, Page. 11

10 S Subijanto, Peran Negara Dalam Hubungan Tenaga Kerja Di Indonesia, Jurnal Pendidikan Dan Kebudayaan, 17, no. 6 (2011), Page. 709 
lives, including being involved in labor matters. The impact of the involvement of the state in labor matters has had the effect of a transitional event in labor law or labor law, which was originally a labor law or labor law is only an aspect of civil law, shifted to aspects of public law or state administrative law. ${ }^{11}$

In the industrial category, the existence of workers is highly recommended, but sometimes the payment of Indonesian workers is arguably very low or very cheap if it is equated with other developing countries. With a low pay but the higher labor production power makes a company or business get a big profit. In labor welfare, the government has an obligation that is responsible for maintaining labor rights and obligations with existing rules. But that is often not done. Even the government does not perform its role to defend labor rights. In reality, the government does the opposite by lowering the minimum wage standard for workers below the appropriate standard. ${ }^{12}$

For the creation of a conducive state economy, the role of the government is very important. Because the government is the executor of the regulator which should know about what is needed by the executor of the business world which includes workers who sometimes distinguish or discriminate against their status in the structure of society. The government must be fair in making and implementing regulations without any benefit or disadvantage to either party. The government in national hunting also needs to prioritize social quality, including making regulators or regulations that guarantee labor rights by companies.

Workers should get the right to prosperity for their lives. As said by the Central Board of the Association of Indonesian Independent Workers Union (Gaspermindo) Moh Jamhur Hidayat stated that, judging from the current level of welfare each worker is only one sixth (1/6) of the average national wealth per capita which reaches 3,000 US dollars Serkat (US) per year. In a national establishment, laborers / laborers have a very important degree as an agent and development goal. Based on this phenomenon, it is necessary to have a strategy in the development of manpower in advancing the capacity of laborers or laborers themselves in order to increase the protection of their rights in bringing their families in accordance with expectations, dignity and humanity. Employment development aims:

a. Empower and optimize the workforce to the maximum and humanity.

b. Giving birth to equality of work and labor design for workers or labors in accordance with the interests of national and regional development.

c. Providing security to workers in bringing prosperity.

d. Foster the welfare of the workforce and their families. ${ }^{13}$

11 Ahmad Hunaeni Zulkarnaen, Masalah Rawan Dalam Hubungan Industrial Dan Konsep Negara Kesejahteraan Indonesia, Jurnal Hukum Mimbar Justitia, 2, no. 2 (2018), Page. 808

12 Firmansyah, Meningkatkan Kesejahteraan Kehidupan Para Buruh Di Era Globalisasi Yang Dihadapi Bangsa Indonesia, Jurnal IImiah Widya, 5, no. 2 (2018), Page. 337

13 Ibid. 
In accordance with Law Number 39 of 1999 concerning Human Rights (HAM) Article 38 states that:

a. Every citizen, according to their talents, skills and expertise has the right to decent work.

b. Each person independently chooses the job he likes with the right to work conditions.

c. Everyone, both men and women carry out the same work, equal, balanced or in accordance with the terms of the same employment agreement.

d. Everyone, both men and women, in carrying out work that is of the same standard with the dignity of a fair wage in accordance with the dignity of a fair wage in accordance with their performance and can save the survival of their family life. ${ }^{14}$

The existence of economic development and in other fields continues to increase causing human resources are also influential. Because it will be an actor in development such as labor or workers. Even the high quality of the population or life of a country can have an impact that causes the unsecured success of development may be a threat to the sustainability of the development. Even if it is too high it will cause inequality such as the unavailability of jobs and the impact of part of the population at the elderly level not getting a job. ${ }^{15}$

In the law of manpower has arranged in such a way the relationship between workers or laborers with employers, which controls the rights or interests of individuals. Rights and obligations obtained by workers or labors must be given in accordance with the agreements that have been made as best as possible. Protection of rights for workers or laborers means that relations in establishing work remain peaceful without pressure or threats from the strong to the weak. ${ }^{16}$

In fact, the government has made efforts to create industrial ties for workers, which started from the beginning of independence and even after the end of President Soeharto's government, the government declared Labor Law No. 25/1997, which was by the workers / laborers as well as human rights activists are opposed to being applied. In the end, the rejection of the Act resulted in the postponement of the implementation of the Act by President Habibi. ${ }^{17}$

\section{Form of Legal Protection Provided by The Country of Labor Rights in The Situation of Covid-19 Pandemic}

Indonesia is a country that must be based on law from various

14 Suci Flambonita, Perlindungan Hukum Terhadap Hak Pekerja Perempuan, Simbur Cahaya, 24, no. 1 (2017): 4404,

15 Rini Sulistiawati, Pengaruh Upah Minimum Terhadap Penyerapan Tenaga Kerja Dan Kesejahteraan Masyarakat Di Provinsi Di Indonesia, Jurnal Repository Polnep, 8, no. 3 (2013), Page. 196

16 S Suhartoyo, Perlindungan Hukum Bagi Buruh Dalam Sistem Hukum Ketenagakerjaan Nasional, Administrative Law \& Governance Journal, 2, no. 2 (2019), Page: 328

17 Ibid. 
aspects. That statement is in accordance with the 1945 Constitution article 1 paragraph (3) which reads "(3) The State of Indonesia is a state of law." Therefore, Indonesia guarantees the fulfillment and protection of the human rights of its inhabitants. The state has an obligation in carrying out the survival of its citizens. That guarantee can be seen in the implementation of labor law protection in getting their rights. The guarantee includes matters that support in carrying out work which is also useful in the life of the workers themselves.

The meaning and intention of the legal protection itself is the use of protection based on the understanding of the law so that the legal protection is also based on the applicable law. It was intended with a particular interest which is the estuary of that is to make it a legal right. Then a right is considered as a subjective law which means norms or a teaching.

Public interest is included in the legal function where as we know, the legal function can also be linked to legal protection. In the book entitled "Crime and Costum In Savege", authored by Bronislaw Malinowski, says that the role of law is not only in situations that are full of violence and conflict, but that law also plays a role in daily activities. ${ }^{18}$

The position of workers is on the marginal side. Therefore, workers are in dire need of legal protection. Legal protection is used to protect the rights of workers and to protect workers from discrimination in order to achieve prosperity within the scope of work.

Article 5 of Law Number 13 Year 2003 concerning Manpower expressly regulates the protection of workers. The contents of the article namely, the equal opportunity each worker has in obtaining decent work and livelihood without regard to differences such as gender, ethnicity, race, religion, and political flow in accordance with the interests and abilities of the workforce concerned, including the same treatment of persons with disabilities. Then in article 6 requires employers to provide workers' rights and obligations without differentiating gender, ethnicity, race, religion, color, and political flow. The following are the rights that workers have in the labor law:

a. Article 11 , contains the right to renew or grow potential.

b. Article 12 paragraph (3), contains the right to receive training.

c. Article 31, junto Article 88, contains the right to determine the type or variety of work and determine income originating from domestic or abroad.

d. Article 86 paragraph (1), contains the right to health and safety at work.

e. Article 99 paragraph (1), contains the right to obtain Workers' Social Security (Jamsostek) for workers and families.

f. Article 104 paragraph (1), contains the right of workers to form or become members of trade unions. 
From the clarification of the regulations in the article above, we can draw conclusions about the protection obtained by workers: ${ }^{19}$
a. The right to negotiate with employers or work owners,
b. The right to safety and health in performing work,
c. Exclusive protection for women workers, children, and for people with disabilities,
d. Protection regarding wage systems, peace and Social Security.

However, with the current situation, namely the situation of the pandemic Coronavirus Disease 2019 (Covid-19), many workers were harmed by employers or work owners and suffered losses such as no longer getting their rights. Therefore, to overcome this, the government intervened to carry out legal protection of the rights of workers.

The most pronounced impact of the existence of this outbreak for workers is such as the existence of polemic in the provision of wages until even the occurrence of Termination of Employment (FLE) carried out by companies with large numbers. The incident occurred in most countries that were also affected by this outbreak. In Indonesia, there were 2.8 million workers who were affected by this outbreak.

\section{Problems faced by workers/laborers during the Coronavirus Disease 2019 (COVID-19) Pandemic}

a. Problems in the field of wages during Coronavirus Disease 2019 (COVID19)

Regarding the actual wages of workers have been regulated in Government Regulation (PP) Number 78 of 2015 concerning Wages. Currently, many companies make wage deductions on the pretext that the company suffers losses. Such reasons cannot be justified and are even considered to be based on no applicable law because they are considered to lead to disputes over rights.

With the reason the company suffered losses and decreased turnover and income for the company due to this pandemic, the company not only did wage deductions, the company also could not complete the wages that were entitled to workers who were set according to the provincial minimum wage (UMP). Companies that experience these problems by the government are not allowed to cut wages or even lay off workers.

Then solving the right problem to overcome this is referring to Law No. 13 of 2003 concerning Manpower in article 90, No. KEP-231 / MEN / 2003 of 2003 which regulates the Procedures for Suspending the Implementation of the Minimum Wage which is the result of a decree of the Minister of Manpower and Transmigration.

The point is that the postponement of wages can be done by the company but must be based on the applicable provisions by first submitting to the Governor that he will postpone the payment of wages

19 Eko Wahyudi, Hukum Ketenagakerjaan, Sinar Grafika, Jakarta, 2016 
to workers.

If the wage suspension effort is met or approved by the governor, the governor will issue a Governor Decree in which the company may pay workers' wages below the Provincial Minimum Wage (UMP) and then the rest can be paid the following year. In the work environment, matters governing the handling and prevention of the presence of a pandemic Coronavirus Disease 2019 (COVID-19), namely Circular Letter (SE) of the Minister of Manpower Number M / 3 / HK.04 / III / 2020 which regulates the Protection for Workers / Workers and Continuing Efforts to Avoid and Control the Coronavirus Disease 2019 pandemic outbreak (COVID-19).

Form of steps to avoid and control pandemic outbreaks related to Coronavirus Disease 2019 (COVID-19) in the work environment Circular Letter (SE) Minister of Manpower Number M / 3 / HK.04 / III / 2020. In this Minister of Manpower Letter, it is stated that each Governor is appointed and asked to protect wages for workers / laborers regarding the Coronavirus Disease 2019 (COVID -19) outbreak as well as to prevent, handle and spread cases regarding Covid-19 within the scope of labor work: ${ }^{20}$

1) Workers or labors when their status as Monitoring Insider (ODP) according to the doctor and not work for a maximum of 14 days then the wages must be paid in full.

2) Workers or labors suspected of Coronavirus Disease 2019 (COVID19) are quarantined according to doctors, so during the quarantine period they are still paid in full.

3) Due to illness or suffering from a positive Coronavirus Disease 2019 (COVID-19), workers' wages are paid according to the laws.

But if a company restricts activities within the scope of the company due to reducing the risk of transmission of this virus which requires reducing the number of workers. In other words, laying off workers for a while, then wage payments are set according to the agreement between the worker and the company.

b. Problems with layoffs during Coronavirus Disease 2019 (COVID-19)

In the Manpower Law (Law No. 13 of 2003) there are no known terms governing "laying off workers". However, many companies do this because the company experiences certain conditions, such as stopping production until due to a certain crisis affecting the company. The term "laying off workers" means workers or laborers are not laid off but only housed with the note that when the company returns to normal, the laid off workers will be called to work again.

In article 151 precisely in paragraph (1) of Law No. 13 of 2003 concerning Manpower states that the employer or in this context the company, the partnership of workers, and workers with all efforts must make every effort to avoid termination of employment. That implies that, the employer should not make a policy of Termination of Work

20 Yenti Sumarni, Manajemen Ekonomi Islam Dalam Menangani Pandemi Coronavirus Disease (COVID-19) Di Indonesia, Jurnal Baabu Al-IImi , 5, no. 1 (2020), Page, 122 
Relationship (FLE) directly to workers even with the reason for the ongoing outbreak of the virus as it is today.

However, if the event or the policy cannot be prevented, then the protection of the rights for labor arrangements must be based on CHAPTER XII (12) of Article 150 through Law Article 172 No. 13 of 2003 and based on Law No. 2 of 2004 concerning Settlement of Industrial Relations Disputes. ${ }^{21}$

But there are several reasons that allow the dismissal to take place, namely: (1) Forcefulness or also known as Force majeure with the condition that the coercion is not desired by all parties. then the next reason (2) is "efficiency", but with these two reasons the company or employer must complain about the financial condition of the company or employer for the last two years which must be in accordance with the facts and then the finance has been audited by an accountant with note: it has suffered financial losses. This is contained in Article 164 paragraph (1) and paragraph (2) of Law No. 13 of 2003 concerning Manpower.

In carrying out efficiency, the employer conducts layoffs provided there is no other way out. That is regulated in Article 164 paragraph (3) of Law No. 13 of 2003, Decision of the Constitutional Court (MK) Number: 19 / PUU-IX / 2011 as follows:

"Employers can only lay off workers for reasons of efficiency which must be interpreted as a Permanent Shut Company or the Company does not temporarily close". 22

If Force Majeure is imposed on an employee and then the employee is laid off by the employer, the worker must get one time severance pay based on the Law Article 156 paragraph (2) of the Manpower Act No. 13 of 2003, money for appreciation or work honor as many as one time with the legal basis of Article 156 paragraph (3), and compensation money according to the provisions of article 156 paragraph (4). ${ }^{23}$

But when Efficiency is applied to workers, then the worker has the right to get twice as much severance payments on the basis of Article 156, precisely in paragraph (2) of the Manpower Act Number 13 of 2003, giving a one-time honorarium or honorarium for work on a legal basis Article 156 paragraph (3) and transfer of rights in accordance with Article 156 paragraph (4).

c. A form of government protection or program for workers who are laid off or laid off during the Coronavirus Disease 2019 (COVID-19) pandemic.

1) This Work Card is issued by the Government on April 11, 2020

Based on PP No. 36 of 2020 concerning the Development of

21 Niru Anita Sinaga, Analisis Perlindungan Hukum Tenaga Kerja Dalam Pelaksanaan PHK, Jurnal IImiah Hukum Dirgantara, 4, no. 2 (2014), Page. 23

22 Andika Pramana Putra, Kajian Hukum Terhadap Putusan Mahkamah Agung Atas Perkara No.825k/Pdt.Sus-Phi/2015 Tentang Pemutusan Hubungan Kerja Karena Alasan Efisiensi, Jurnal Hukum Adigama, 1, no. 1 (2018), Page. 21

23 Ibid. 
Work Competencies through the Pre-Work Card Program, after which the Minister of Finance Regulation (PMK) No. 25 / PMK.O5 / 2020 was issued regarding the Procedures for Allocating, Budgeting, Disbursing, and Accountability of the Workers Card Fund, officially launched. ${ }^{24}$

Then the Presidential Instruction (Inpres) No. 4 of 2020 was issued, in which the 2020 Workers Card was explained, namely on Budget Reallocation, Re-focusing Activities, and Procurement of Goods and Services for the Acceleration of Coronavirus Disease 2019 (Covid-19). ${ }^{25}$

a) People who are entitled to receive a Work Card

The target of this pre-employment card program is for workers who have experienced Termination of Work (FLE) in their work environment and for Micro Enterprises run by the community and their businesses are affected by the outbreak of Coronavirus Disease 2019 (COVID-19). But not only for victims of Termination of Employment (PHK) and for Micro and Small Enterprises (MSE) affected by this virus are the targets of this pre-employment card program, but also for the unemployed and also for young people who have just finished schooling (formal education).

b) Work Card Budget

The original budget of $\mathrm{Rp} 10$ trillion was raised to $\mathrm{Rp} 20$ trillion in $2020 .{ }^{26} 5.6$ million unemployed are designed to be absorbed by this program.

c) The amount of financial assistance received by the Workers Card participants

Participants of the Pre-Employment Card program will receive incentives and training assistance totaling $\mathrm{Rp} 3,550,000$. The details, the training assistance costs Rp. 1 million, the incentive to complete the training is Rp. 600,000 per month for four months, and the employment survey incentive is Rp. $150,000 .^{27}$

d) Benefits of the Pre-Work Card for participants

For people who take part in this program and then are selected as participants, they will get the benefit of free online training that is borne by the government in the hope that the participants will get new skills to be used as capital to get a job or

24 Yoshua Consuello, Analisis Efektifitas Kartu Pra-Kerja Di Tengah Pandemi Covid-19, 'ADALAH, 4, no. 1 (2020), Page. 95

25 Henny Juliani, "Analisis Yuridis Kebijakan Keuangan Negara Dalam Penanganan Pandemi Covid-19 Melalui Peraturan Pemerintah Pengganti Undang-Undang Nomor 1 Tahun 2020," Online Administrative Law \& Governance Journal 3 (2020): 2621-2781

26 Lan T. Phan et al., Importation and Human-to-Human Transmission of a Novel Coronavirus in Vietnam, New England Journal of Medicine, 382, no. 9 (February 27, 2020), Page. 87274

27 Rahma A Mardiyah, Dampak Pandemi Covid-19 Terhadap Peningkatan Angka Pengangguran Di Indonesia, Jurnal Ilmu Hukum, 2, no. 1 (2020), Page. 13 
start new entrepreneurs in the midst of the layoffs of workers. ${ }^{28}$

2) A cash-intensive program promised by the President.

The understanding of cash for work is a result of government policies issued with the aim of providing guidance to marginalized communities, unemployment and for children who have malnutrition by utilizing natural resources, labor, and local technology as an effort to overcome the poverty, increase income and stunting decrease numbers. $^{29}$

President Jokowi issued a labor-intensive program whose purpose is none other than to reduce / reduce the poverty rate that exists in Indonesian society. It is also expected to provide relief for people who lose their daily work due to the pandemic Coronavirus Disease 2019 (COVID-19).

a) Labor intensive form

The forms of cash-intensive programs are many, but with this pandemic, it is possible to do such things as making masks, disinfectants, or even personal protective equipment and other devices that can neutralize the Coronavirus Disease 2019 (COVID19) virus outbreak.

For rural communities affected by this virus, cash intensive labor programs can also be used using village funds, namely as social assistance for villagers to ensure the survival of the villagers during the Coronavirus Disease 2019 (COVID-19) virus.

b) A cash-intensive target

Cash intensive is aimed at poor, unemployed, or underemployed families.

\section{Conclusion}

Welfare can be achieved by workers when their needs are met, both physical and spiritual needs. In this way an association or labor union is formed which is tasked with channeling the opinions or suggestions of workers to form an industrial involvement by passing through the company. As a form of welfare given to laborers can be realized through the provision of labor rights and decent wages, but that is still often not done well.

The form of protection or government programs for workers who have been laid off (PHK) due to the Coronavirus Disease 2019 (COVID -19) pandemic, namely issuing Pre-Work Card And Cash-Intensive Programs. The two programs have the same goal to overcome the problem of unemployment in Indonesia.

28 Najella Zubaidi, Gusti Pratama, and Sholahuddin Al-Fatih, Legal Perspective on Effectiveness of Pre-Work Cards for Indonesian People, Jurnal Bestuur, 8, no. 1 (2020)

29 Tiara Rama Dian, Pemberdayaan Masyarakat Melalui Program Padat Karya Tunai (Studi Kasus Desa Plandaan Kecamatan Kedungwaru Kabupaten Tulungagung), Jurnal Publika, 4, no. 1 (2019), Page. 3 


\section{BIBLIOGRAPHY}

\section{Book :}

Eko Wahyudi. 2016. Hukum Ketenagakerjaan. Sinar Grafika. Jakarta;

Qamar, N, M Syarif, DS Busthami, MK Hidjaz, and A Aswari. 2017. Metode Penelitian Hukum (Legal Research Methods). CV. Social Politic Genius (SIGn). Makassar;

Soeroso. 2006. Pengantar IImu Hukum. Sinar Grafika. Jakarta;

\section{Journal :}

Anita Sinaga, Niru. Analisis Perlindungan Hukum Tenaga Kerja Dalam Pelaksanaan PHK. Jurnal Ilmiah Hukum Dirgantara, 4, no. 2, 2014;

Consuello, Yoshua. Analisis Efektifitas Kartu Pra-Kerja Di Tengah Pandemi Covid-19" 'ADALAH , 4, no. 1, 2020;

Dian, Tiara Rama. Pemberdayaan Masyarakat Melalui Program Padat Karya Tunai (Studi Kasus Desa Plandaan Kecamatan Kedungwaru Kabupaten Tulungagung). Jurnal Publika , 4, no. 1, 2019;

Firmansyah. Meningkatkan Kesejahteraan Kehidupan Para Buruh Di Era Globalisasi Yang Dihadapi Bangsa Indonesia. Jurnal I/miah Widya, 5, no. 2, 2018;

Flambonita, Suci. Perlindungan Hukum Terhadap Hak Pekerja Perempuan. Simbur Cahaya, 24, no. 1, 2017;

G Hendrastomo. Menakar Kesejahteraan Buruh: Memperjuangkan Kesejahteraan Buruh Diantara Kepentingan Negara Dan Korporasi. Jurnal Informasi, 16, no. 2, 2010;

Jauhari Ginting, and Indah Kurnia Ningsih. Perlindungan Hukum Terhadap Pekerja PT. Mara Jaya Dalam Hal Kebebasan Berserikat Menurut Undang-Undang RI Nomor 21 Tahun 2000 Tentang Serikat Pekerja. Jurnal Hukum Kaidah: Media Komunikasi Dan Informasi Hukum Dan Masyarakat, 19, no. 1 2019;

Juliani, Henny. Analisis Yuridis Kebijakan Keuangan Negara Dalam Penanganan Pandemi Covid-19 Melalui Peraturan Pemerintah Pengganti Undang-Undang Nomor 1 Tahun 2020. Online Administrative Law \& Governance Journal, 3, 2020;

Kahfi, Ashabul. Perlindungan Hukum Terhadap Tenaga Kerja. Jurnal Jurisprudentie, 3, no. 2, December 1, 2016;

Mardiyah, Rahma A. Dampak Pandemi Covid-19 Terhadap Peningkatan Angka Pengangguran Di Indonesia. Jurnal Ilmu Hukum, 2, no. 1 2020;

Phan, Lan T., Thuong V. Nguyen, Quang C. Luong, Thinh V. Nguyen, Hieu T. Nguyen, Hung Q. Le, Thuc T. Nguyen, Thang M. Cao, and Quang D. Pham. Importation and Human-to-Human 
Transmission of a Novel Coronavirus in Vietnam. New England Journal of Medicine, 382, no. 9, February 27, 2020;

Putra, Andika Pramana. Kajian Hukum Terhadap Putusan Mahkamah Agung Atas Perkara No.825k/Pdt.Sus-Phi/2015 Tentang Pemutusan Hubungan Kerja Karena Alasan Efisiensi. Jurnal Hukum Adigama, 1, no. 1, 2018;

S Subijanto. Peran Negara Dalam Hubungan Tenaga Kerja Di Indonesia. Jurnal Pendidikan Dan Kebudayaan, 17, no. 6, 2011;

S Suhartoyo. Perlindungan Hukum Bagi Buruh Dalam Sistem Hukum Ketenagakerjaan Nasional. Administrative Law \& Governance Journal, 2, no. 2, 2019;

Silpa Hanoatubun. Dampak Covid - 19 Terhadap Perekonomian Indonesia. EduPsyCouns: Journal of Education, Psychology and Counseling, 2, no. 1, April 14, 2020;

Sohrabi, Catrin, Zaid Alsafi, Niamh O’Neill, Mehdi Khan, Ahmed Kerwan, Ahmed Al-Jabir, Christos Iosifidis, and Riaz Agha. World Health Organization Declares Global Emergency: A Review of the 2019 Novel Coronavirus (COVID-19). International Journal of Surgery, 76, April 1, 2020;

Sulistiawati, Rini. Pengaruh Upah Minimum Terhadap Penyerapan Tenaga Kerja Dan Kesejahteraan Masyarakat Di Provinsi Di Indonesia. Jurnal Repository Polnep, 8, no. 3, 2013;

Sumarni, Yenti. Manajemen Ekonomi Islam Dalam Menangani Pandemi Coronavirus Disease (Covid-19) Di Indonesia. Jurnal Baabu A/IImi, 5, no. 1, 2020;

SW Handayani. Jaminan Pemerintah Negara Republik Indonesia Terhadap Penyelenggaraan Serikat Pekerja Sebagai Hak Azasi Manusia. Kosmik Hukum, 16, no. 1, 2016;

Yosephine Marcella, and Komang Pradnyana Sudibya. Peran Organisasi Serikat Pekerja/Buruh Dalam Pembangunan Perekonomian Indonesia. Kertha Semaya: Journal IImu Hukum, 4, no. 3, 2018;

Zubaidi, Najella, Gusti Pratamab, and Sholahuddin Al-Fatih. Legal Perspective on Effectiveness of Pre-Work Cards for Indonesian People. Jurnal Bestuur, 8, no. 1, 2020;

Zulkarnaen, Ahmad Hunaeni. Masalah Rawan Dalam Hubungan Industrial Dan Konsep Negara Kesejahteraan Indonesia. Jurnal Hukum Mimbar Justitia, 2, no. 2, 2018; 